\title{
Censorship in Malawi
}

Malawi is an example of the utter extremes of press censorship. It never experienced press freedom until 1993. The Malawi people are still bitter after three decades of Banda's rule. The people's new experience in press freedom has given them their first taste of democracy.

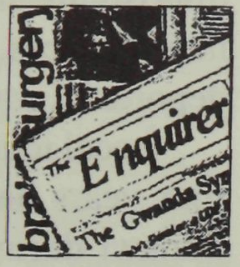

\section{By Fr TREVOR CULLEN}

ILIVED in Malawi for ten years from 1981-92. My article tells how the Malawi Government controlled the media and the damaging effect it had on public morale.

Malawi is a small landlocked country bordered by Tanzania, Mozambique and Zambia. It is about the size of England and has a population of about eight million. Malawi gained independence from Britain in July 1964. Hastings Banda was elected its first Prime Minister and President for life in 1966. He and his Government, the Malawi CongresS Party, were toppled from power in May 1994. Banda ruled like a dictator from the very start. He employed a small army of spies and a large number of police to enforce his dictatorial reign. His brutal régimel ed some political commentators to describe Malawi as the 'Romania of Africa'. Thousands were tortured and killed during his rule.

The media during Banda's reign

President Banda used the press to bolster his political dominance. For example, the 1968 Censorship Bill made it an offence - punishable by five years' imprisonment - 'to publish anything likely to undermine the authority of, or public confidence in the government'. The scope of the bill removed any loopholes in previous regulations in regard to freedom of speech. From that time on, Banda gradually took control of every aspect of the country's media.

Banda owned the only two newspapers in Malawi - The Daily Times and Malawi News. Malawi's only radio station, Malawi Broadcasting Corporation (MBC), was Government-run. The country has no television. Amnesty International described the role of the media in Malawi as 'primarily to catalogue the 


\section{TREVOR CULLEN}

head of State's words and activities'. Foreign publications were vetted for anything that might be critical of any aspect of political, economic or social life. Critical articles about Banda were ripped out of Newsweek and Time magazines. Foreign correspondents were frequently expelled. Mike Hall worked for 18 months as the BBC.'s Malawi correspondent. He told me in an interview: 'Operating in Malawi was extremely difficult. I had no access to cabinet ministers and little rapport with local journalists because they could get life imprisonment for passing on information. Diplomats and aid workers were my main sources. In February 1990, I was told to leave the country or I would be deported. I was never told the reasons and had 48 hours to pack my belongings.'

Local journalists were detained (some for years). One, John Mbula, served four years haRd labour for reporting on the effects of drought in southern Malawi during the mid-1980s. The drought was severe. Hundreds died but Banda wanted to give the impression to the outside world that Malawi had no problems. People felt betrayed by the press. It seemed there was no one to expose Government abuses or voice the people's concerns.

The Malawi Censorship Board was set up in 1975. In its first year it banned 849 books, 1000 periodicals and 16 films. The media was so tightly controlled that Malawians turned into the $\mathrm{BBC}$ to find out what was happening in their own country.

\section{My own experience of press censorship}

As editor of a quarterly youth magazine, Along the Way, I had to take each issue to the Censorship Board for approval. I was told that the magazine would be banned if they found any critical statements in it. When I gave weekly religious radio talks they would edit any reference I made to moral leadership or responsibility in Government activities. Even when I preached on Sunday, there was always at least one Government spy in the congregation. You never knew who they were. Everyone just became experts in self-censorship.

\section{Banda's overthrow and the birth of press freedom}

President Banda's near-total control of the country - especially the press lasted nearly 30 years. It came to a dramatic end in 1992 when Malawi's seven Catholic bishops published a letter condemning Banda's appalling human rights record. It was the first time anyone had publicly criticised Banda and his Government. The bishops were immediately arrested and charged with sedition. At a hastily arranged meeting of top Government officials it was decided that the bishops should be killed. Fortunately, they were not killed. One basic reason was that the Malawian people came out onto the streets in their thousands in support of what the bishops had written about corruption, poverty and censor- 


\section{MALAWI MEDIA}

ship. It was an 11-page document and the part on the press reads:

Monopoly of the mass media and censorship prevents the expression of dissenting views; some people have paid dearly for their political opinions. This is most regrettable. It creates an atmosphere of resentment among the citizens. It breeds a climate of mistrust and fear. The fear of harassment generates a society where the talents of many lie unused and where there is little room for initiative. ${ }^{1}$

The bishops were merely repeating the content of an earlier church document on press freedom and the right to information: 'There exists therefore in every human society a right to information on the subjects that are of concern to people either as individuals or as members of society. ${ }^{2}$ The document also cautioned that the content of communication be true and that 'it should be communicated honestly and properly'.

I was in London when the bishops faxed me a copy of their letter with the words: 'We need protection. Get it on the BBC. The day the letter was read out in every church in Malawi, I was interviewed by the BBC. I said what the bishops had written was absolutely true. Within days, I was informed that the Government had banned me from Malawi.

Public demonstrations in support of the bishops' letter, together with international condemnation and economic sanctions, forced Banda to hold multiparty elections in May 1994. He lost and, at 94, he is now under house arrest for ordering the murder of three cabinet ministers in 1983 for disagreeing with his leadership style.

I returned to Malawi in 1993 to do a series of interviews for a book on Banda. It was published in 1995 and is entitled Malawi: A Turning Point.

\section{The present state of press freedom}

Malawi now has no fewer than 21 uncensored newspapers. It is the most visible sign of change since Banda's removal. Mostly, they are four or eight page tabloids operating on a shoestring budget. Some of the reporting is speculative and inaccurate but most papers adopt a responsible and restrained approach. There are frequent scathing attacks against Banda.

One newspaper, The Monitor, concluded one editorial by claiming that 'the best Banda's Government did was to make Malawians brainless, thoughtless and spineless.' Many commentators say that Malawi's new independent press will be one of the lasting benefits of a multiparty régime. If some of the papers survive it will force the new Government to behave in a more transparent and accountable way. 


\section{Final thoughts}

Malawi is an example of the utter extremes of press censorship. It never experienced press freedom until 1993. The Malawi people are still angry and bitter for being suppressd and stunted for so long. They could never really develop as a people or as a nation under Banda's state censorship. However, this new experience of press freedom has given the people their first taste of democracy. They are determined to hold onto it. Fear and mistrust of the Government have gradually been replaced by open debate and dialogue on Malawi's future. People now feel they are in some small way participants in the country's future.

Finally, it was like a breath of fresh air arriving in Papua New Guinea after ten years in Malawi's heavily censored society. The degree of press freedom that you enjoy here is something that we fought hard for in Malawi. I hope we keep up the same pressure to preserve it as the basic right for every individual, community and country.

\section{Notes:}

1. Extracts from the Catholic bishops' letter, March 1992.

${ }^{2}$. Vatican II documents, Inter Mirifica, 1963.

$\square$ Fr Trevor Cullen is the author of Malawi: A Turning Point and the head of journalism at the Divine Word Institute, Madang. He gave this paper at the 'Freedom at the Crossroads' media seminar in Port Moresby, 29 February-1 March 1996. 